\title{
Changing Strategies for Russian Companies in the Conditions of Economic Crisis: The Experience of a Monographic Study
}

\author{
Liudmila Ruzhanskaya \\ Elena Yakimova \\ Ural Federal University, 620083, Russia, Ekaterinburg, Lenina st., 51
}

\author{
Doi:10.5901/mjss.2015.v6n3s3p365
}

\begin{abstract}
This article covers stable patterns of economic behavior of Russian enterprises within the frames of the two previous economic crises of 1998-1999 and 2008-2009, as well as anti-crisis actions in the modern conditions. The empirical bases of this research were depth interviews with persons responsible for strategic decisions making at three enterprises operating within the Ural region and Russia. Interview materials of the experts are supplemented with the data about management and financial accounting of the companies, and with the reviews of the companies' major products markets.
\end{abstract}

Keywords: economic behavior of enterprises, economic crisis, anti-crisis actions, strategic decisions

\section{Introduction}

Economic crises in Russia are frequently induced by two factors - falling oil prices and the necessity to pay foreign debts. During three crises (at the end of the 1980s, in 1998 and in 2008), a falling oil price and a sudden stop in foreign lending always happened simultaneously. In the process of devaluation in 1998, funds withdrawal by western banks from the Government Short-Term Bonds (GSTB) played a role at least equal to the role of the oil price. The Central Bank and the Government entered the crisis of 2008 with a substantial monetary buffer, however, in the process of the "scheduled devaluation", corporations and banks received the most of such reserves in the form of exchange market interventions. Duration of the current recession will be determined by the speed of oil price recovery (of the "bounce" along the socalled V or L trajectories). In the crises of 1998 and 2008, bargain sales on the oil market lasted not long, and the recovery was quite drastic. In the current situation, the UBS Bank forecasts that the combination of soft demand and excessive supply can extend prices recovery for a period of up to 60 months. Overloading of the Russian banks and corporations being primarily under state control with the foreign debt combined with the sanctions caused the unprecedented ruble's collapse - even against the background of other "commodity" and "non-commodity" minor currencies. In the beginning of the year, the cost of the credit default swap (CDS) under the Russian government debt increased up to $5.74 \%$ per year against $2.5 \%$ in the beginning of November. The drop of the Russian sovereign rating into the "garbage" zone will be definitely followed by similar downshifting of Russian companies.

Throughout recent months, the Ministry of economic development added two new scenarios to its forecast, based on the oil price forecast. Forecast of the GDP fall by $3-4 \%$ can be possibly considered as a consensus. Apparently, it will take place at the expense of trade and construction, partial industry releasing investment products, and the IT-service (Zhuravlyov, 2015).

According to the large-scale poll (752 industrial enterprises) carried out in 2009 by the National Research University - the Higher School of Economics within the frames of the second round of production competitive ability monitoring, enterprises of all scales and industries experienced crisis consequences. There were three most acute of them: the diminution of demand for products, the growth of non-payments by suppliers, and the growth of borrowing costs. Large enterprises with the headcount over 1,000 employees suffered more from the crisis, as they had more loans. Besides, the crisis produced a slight impact on more innovative enterprises, which had made large investments in 20052008.

For the time being, actions taken by industrial enterprises in response to the crisis can be assessed as primarily conservative. Among the steps taken by the enterprises, it is possible to single out the typical ones such as:

1. Delayed payments to suppliers,

2. Shifting part of employees to a half-time week or their removal to non-paid vacations, 
3. Output reduction and rejection of new investment projects.

Average share of all interviewed enterprises, which used such measures, fluctuated from 44 to $47 \%$ of the selection.

"Active adaptation" strategies were represented by entries to new markets and search of new customers ( $41 \%$ of the sampling). Such strategy became characteristic for the large innovatively active companies from regions with an average potential and located in cities with average population.

Price reduction was applied by one third of enterprises, primarily by exporting enterprises. Price growth was applied by companies partially state-owned.

In the whole, according to assessments of enterprises' managers, the situation in the industry looked better than it was presented by macro data about the growing unemployment, non-payments between enterprises, and debts accumulation in the banking sector in 2008-2009. Existence of satisfactory assessments of the financial state among the vast majority of managers, as well as investment plans preservation among the significant number of companies was indicative of the economic growth reserves at the companies' level (Yakovlev, 2009).

Is the same situation observed in the current crisis? Do Russian companies, which experienced two general economic and multiple industrial crises, have typical anti-crisis steps? How effective is the innovatory side of the anticrisis behavior? What triggers companies to look for atypical measures for maintenance of their competitive state within the industry?

The authors tried to give answers to these questions, relying on the multiple cases research technique.

\section{Literature Review}

One of the first "strategy" concepts was introduced into scientific use in the 1930s by the English economist A. Chandler. Large contribution into this problem development was made by the representatives of the structure and behavior-based approach (E. Mason, J. Bain), the Austrian school (C. Menger, L. von Mises, I. Kirzner, J. Schumpeter, F. Hayek). In contrast to neoclassicists, they studied in their works not the state of equilibrium, but the process of its achievement, developed dynamic models of competitive behavior. Modern Russian economic science has in-depth elaborations of theoretical and methodological problems of the transition stage and strategy formation of the Russian enterprises (see works of A.V. Buzgalin, T. Dolgopyatova, G. Kleiner, S. Malakhov, B.Z. Milner, Yu.M. Osipov, G. Ruzavin).

Among the modern representatives of the foreign economic idea, we should mark R. Ackoff, I. Ansoff, B. Karloff, W. King, D. Kliyaand, J. Kornai, D. Mercer, J. O'Shaughnessy, M. Starr, H. Theil, J. Hentz, and other authors disclosing the issues of the impact of the enterprise internal characteristics and of the external environment of its functioning on the behavior of the enterprise (company), selection of a strategy from multiple options with account of the changing (unstable) external environment, diversity of the enterprise strategy functional forms, particular forms and methods of the strategy development and strategic planning.

\section{Methods}

In the process of research, the multiple cases technique was applied based on the materials of the three companies of different sizes (small, medium, and big business), operating on the regional, all-Russian, and foreign markets with and without foreign capital. The information base of the research was formed by materials of the in-depth interview with top managers of companies, heads of economic departments, data of the management and financial accounting, data of Rosstat, and analytical materials on the markets of the studied companies' major products.

\section{Results and Discussion}

\subsection{Case 1: Anti-crisis strategies of companies on the electric power market.}

Electric power is one of the most significant industries of the Russian economy. It defines development of not only individual states, but of large regions, too. General market growth in Russia in 2010 amounted at average to $3 \%$ per year and decreased in 2013 by $1 \%$. Electric power industry influences on the national welfare growth, state budget replenishment, and plays a special role in provision of the geopolitical interests of the key economic units of certain regions. 


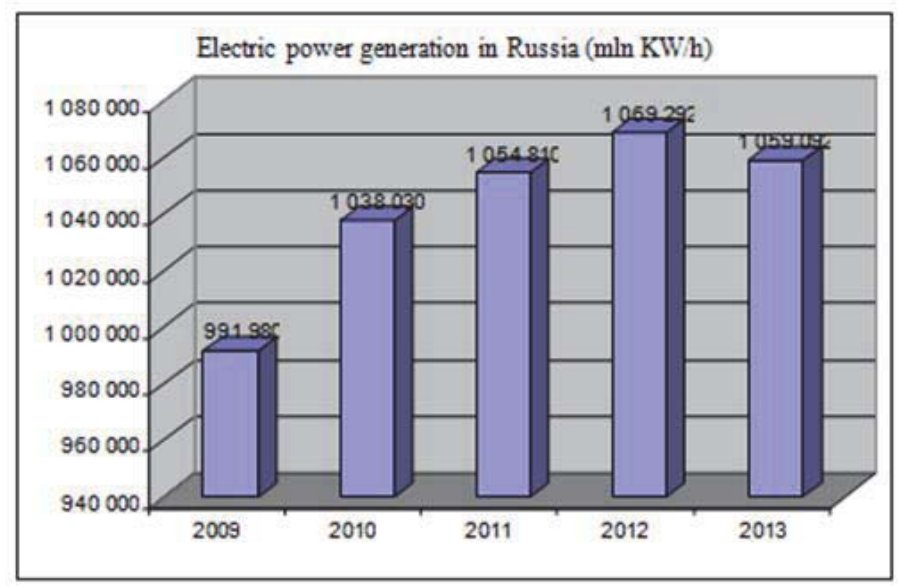

Fig.1. Dynamics of electric energy output, 2009-2013

Source: Data of the Federal State Statistics Service

In the circumstances of globalization and open market development, generating companies cannot be limited merely to their national territories. For their existence maintenance and profit growth, they have to search for new sales markets abroad.

Due to this, prior to developing new business structures, it is extremely important to perform accurate assessment of the foreign markets' role, state, and peculiarities. It is equally important to determine the form of a generating company's entry to a foreign market and its investment strategy.

Transfer to the free market became the core element of reforming, as well as the guarantee of the Russian electric companies' development. Despite the uncertainty and risks typical of this process, the largest global companies started to express their interest towards the Russian electric power industry. Several years ago, a number of such global companies as E.ON (Germany), Enel (Italy), and Fortum (Finland) invested in the Russian electric power market. Attractiveness of the Russian electric power market for foreign investors is primarily determined by the opportunity of effective investment into the developing market with a high growth potential, as in the "old" markets such opportunities degrade, and they need to search for new sales markets.

Capacity supply contracts (CSC) were suggested as a method of solving the issue of generating capacities deficiency. Upon power sales, generating companies acquire obligations on their equipment maintenance in the adequate technical state and continuous readiness for electric power generation. This mechanism provides guarantee of return of investments into construction to the investor. In such circumstances, the sites are constructed in the places with such parameters, which are required for the electric power system (Report on Russian UES performance in 2013).

Only a minor part of investors is ready to invest into Russian electric power without CSC, i.e. without the guarantee of payment for the power and return of investments. Thus, Enriko Viale, the General Director of "Enel Russia", states that the existing capacity market model in Russia has good fundamental grounds; however, it still needs certain follow-up. He said, "In order to provide companies with the possibility of long-term investments planning, it is necessary to perform competitive capacity outtake not for a year, but for four years, as it has been stipulated initially. Besides, it is required to create opportunities of direct contracts simplification between end consumers and generating companies on the " 24 hours in advance" market. (Report on Russian UES performance in 2013).

Enriko Viale also considers that the main distinction of the current crisis phenomena from the situation of 2008 is the crises of the real estate and credit markets, as well as significant decline in GDP growth due to ruble's fall and the political events in "Ukraine-Crimea" (Materials of the interview with Enriko Viale).

Strategic decisions of the company consider the experience of the previous crisis phenomena and are adjusted to different risks induced by the external environment changes. For example, the company's strategy implies carrying out activity on several foreign markets at the same time, which, primarily, allows to maximize earnings; secondly, provides an opportunity of own personnel development by means of experience sharing; thirdly, enables more flexible application of available resources (including HR); fourthly, provides loss compensating mechanisms in case of a crisis in one of the operating countries (Romanycheva, 2014). Such a strategy allows reducing the expenses and avoiding crises connected with rates changes or deviations of another nature. In case of political risks, political and social instability, or a war, the development of the new technologies, services, products, for which electric power is required, or production expansion 
will become a more beneficial strategic solution for the company in contrast to selling the business unit at a lower price.

\subsection{Case 2: Anti-crisis strategies of companies on the dental services market}

The Russian market of chargeable dental services started its active development in the early 1990s. Currently, the market has stabilized in terms of both quantity and quality, having achieved the saturation stage and certain growth limits. According to experts, competitive advantages of the dental business are particularly optimistic for those vertically integrated companies, which are able to focus on rendering highly technical services.

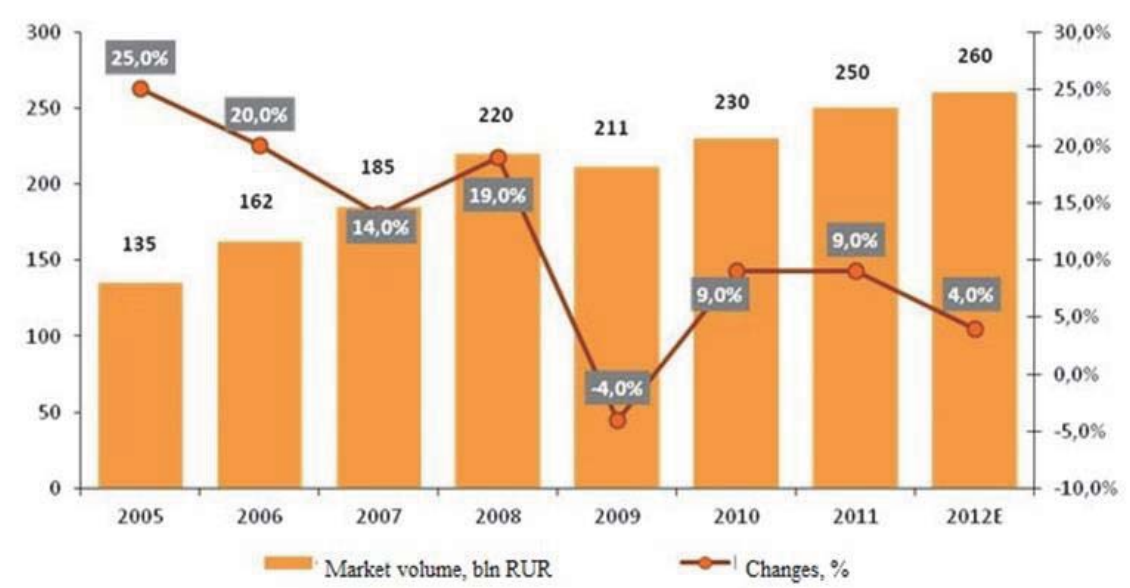

Fig. 2. Dynamics of the volume of chargeable dental services market in Russia, 2005-2012, billion rubles, \% Source: RBK.research

Today it is possible to single out three types of medical institutions on the dental services market (excluding state dental institutions), rendering chargeable dental services:

- Single dental clinics, private dental rooms;

- Networks of dental clinics;

- Medical centers and clinics rendering other chargeable medical services along with dental services.

The dental services market's peculiar feature is the low popularity of the network format. Clinics reluctantly form into networks. Initially, private doctors prevailed in the private medicine structure - their share amounted up to $60 \%$ of the total offer, and today it has reduced to $25 \%$. Experts consider that the most significant trend in the dental services area is the active implantology development, as the competition among manufacturers is quite strong in this niche.

The dental clinic "Belaya Ladya" LLC is a part of the corporate group "Association of Enterprises" and has been operating on the Yekaterinburg market since 1997. The company's structure also includes three branches (in different city districts). Currently, the competitive advantages of the company are:

1. availability of innovative high-technology equipment;

2. active development of marketing technologies in services promotion;

3. cutting production costs by means of dealership technologies.

By the total revenue for 2012-2014, the company can be classified as small business (the total revenue does not exceed USD 0.5 million per calendar year) (Udalova, 2015). In this regard, the company's structure contains no units performing analytical functions. The analysis of the external environment changes is performed only by the direct owner (belaya-ladya.ru). Based on the interview data, it is possible to point out that the management of "Belaya Ladya" was not prepared for the crisis phenomena and did not forecast such a drastic surge of the ruble and real revenues of the population (Udalova, 2015). These factors obviously produce a negative impact on the dental services market both in term of equipment procurement and in sales volumes maintenance. However, the company's management believes that now it is impossible to use Russian manufactured import-substituting products. The crisis of 2008-2009 gave an impulse to the company to revise its strategy, and despite the sustainable growth of the client base and sales, in 2010-2013 certain measures were taken to optimize the company's activity (Udalova, 2015):

1. the administrative staff was reduced by $20 \%$; 
2. equipment supply contracts were concluded on $28-35 \%$ discount terms;

3. the employees' incentive system - for both doctors and administrators - was modified.

Combination of the applied measures allowed cutting the production costs at average by $12-15 \%$. These funds are spent for the customer-focus improvement and promotion.

\subsection{Case 3: Anti-crisis strategies of companies on the transport logistics market}

The high responsiveness of the transport logistics market is one of the key parameters of the Russian territories development, since it vividly illustrates the level of the regions' engagement in the process of products redistribution both domestically and at the global level. The prospects of the shipping and storage sector development are explained by the huge territory of the Russian Federation and its geopolitical position. The market share of the transport and logistics services in 2001 grew by $17 \%$, in 2012 - by $19 \%$, and in 2013 - by 14\%. (RBC, 2014.). Nevertheless, there are also factors, which hamper the industry development in the whole.

At consideration of the logistics services development in the Sverdlovsk region, we can single out several peculiarities. Thanks to the geographical position of the Sverdlovsk region, logistics within the region could take a special niche. Therefore, there is an obvious loss of competitive advantages and financial flows in the region. The regional government still does not consider logistics an effective and independent business industry, as a possible regional specialization, as of a Eurasian transport intersection.

JSC Lorry is a commercial organization carrying out its activity on the territory of the Sverdlovsk region in the field of cargo motor transportation and trade of motor vehicles (Lorry, 2014). The rate of the gross revenue growth of JSC Lorry within 2001-2013 permanently exceeds 30\%, which is one of the key strategic characteristics of the company. The intensity of logistics companies' activity in the concerned region is closely connected with the intensity of the extracting and processing industries operation (RBC, 2014).

In the pre- and post-crisis periods, the company prefers to convert a part of the circulating assets into their absolutely liquid assets (money and securities), thus providing itself with certain income and a financial cushion for the case of an urgent situation on the market. However, in 2009, mutual tendency towards ratio values reduction was observed - the financial crisis "swallowed" all types of assets: from absolute to circulating, including inventories - this occurred due to the growth of expenses for operational activity maintenance and preservation of the strategic position on the market as a "gazelle" during macroeconomic instability.

Owing to the information presented on Figure 2, we can come to a conclusion regarding the company's financial policy pattern: securing the operation with securities and derivatives in the period of economic stability and freezing assets in the form of circulating assets in case of the market stability disturbance.

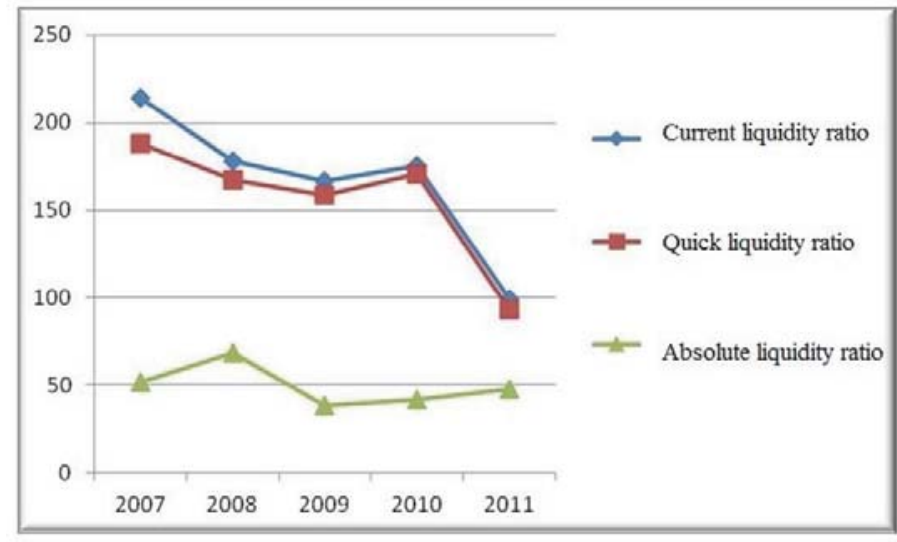

Fig. 3. Changes in the liquidity ratio values in 2007-2011 over time, $\%$

Source: prepared by the author based on the data of the Professional Market and Company Analysis System (PMCAS).

At the same time, the main strategic objective of the company is to ensure the revenues growth.

For this purpose, the company shall primarily plan the strategy of project financing. The strategy is quite simple the company has a perfect credit history. JSC Lorry has six partner banks, five of which are foreign.

One of the development strategies selected by JSC Lorry is to establish subsidiaries, which will be engaged in 
selling products. This variant completely neutralizes the problem of insufficient awareness of regional peculiarities, which arises at direct sales, as the solution of the sales issue is completely addressed by the employees of the subsidiaries. Along with that, the control is still performed by the parent company. A big advantage of this strategy is the possibility to create such a structure of the enterprise, which would be completely integrated into the uniform company structure. It allows using the strengths of the existing company with account of the regional specificity. Upon that, this strategy is one of the least visible, as the increase in the managing staff is very low, and the income is formed in the form of rebate. Today, 14 representative offices of the Lorry Company operate in Russia and render services in different regions.

\section{Conclusion}

In Russia, the society, which is based on the administrative and raw materials revenues, but not on performance and efficiency, has not been reformed yet. The severe transformation crisis (7 years: 1992-1998) was succeeded by the economy recovery through the ruble devaluation (Gonchar, 2008). The import substitution effect became the first stage of the recovery growth, which lasted until 2003. The second stage was marked by the oil market revival. However, no modernization issues were solved both prior to the crisis of 2008-2009 and after it. The reason of the dying rise in labor performance was the preservation of the economy resource model. State investments failed to revive the private ones. (Mironov, 2009). The labor performance rise slowed down, and, consequently, so did the real salary growth (Akindinova, 2014).

In these conditions, for the purpose of competitive recovery, different companies apply typical and atypical strategic steps. Big business having adequate financial strength is able to cover potential losses during several years, and counts on the governmental support. Large companies with the international sharing are ready to not only stay on the Russian market, but also purchase additional assets at a reduced price.

Medium business having significantly smaller financial strength is focused on preservation of the revenue growth rates by means of opening subsidiaries and expanding of the geographic borders of the market. Project financing is accompanied by taking measures for liquidity upsurge.

Small business does not count on the state support, so it has been taking measures to optimize costs and increase profitability since 2010. Since recently, the strategic development of small businesses has included the customer-oriented approach and preservation of the existing customer base.

\section{References}

Akindinova, N.V., Kuzminov, Y.I., \& Yasin, E.G. (2014). Russian economy on the turn (pp. 26). Moscow: Publishing house of the Higher School of Economics.

Gonchar, K.R., \& Kuznetsov B.V., Eds., (2008). Russian industry: Russian industry at the growth stage. Factors of the companies' competitive ability. Moscow: Vershina.

Enriko Viale, (2015) Materials of the interview with the General Director of "Enel Russia".

Udalova N.V., (2015) Materials of the interview with the Development Director of "Belaya Ladya", LLC;

Mironov, V.V. (2009). Impact of the economic crisis on the real economy sector of Russia. Journal of the New Economic Association, 34, 216-225.

Romanycheva, A. (2014). Watts' descent. Situation in the Russian electric power industry. Journal "Kommersant Vlast", 36. Retrieved from: http://www.kommersant.ru/doc/2558347

System Operator of the Unified Power System. Report on Russian UES performance in 2013. Retrieved from http://so- ups.ru/file admin/files/company/reports/disclosure/2014/ups_rep2013.pdf

Website of RosBusinessConsulting. Retrieved from http://www.rbc.ru/, Market Research, 2005-2012.

Website of the Lorry Company. Retrieved from http://www.lorry.com/, Key performance indicators, 2007-2011.

Yakovlev, A.A. (2009). Crisis impact on enterprises' behavior. Journal of the New Economic Association, 3-4, 226-236.

Zhuravlyov, S. (2014) Crisis anatomy. Expert, 7(933), 44. 